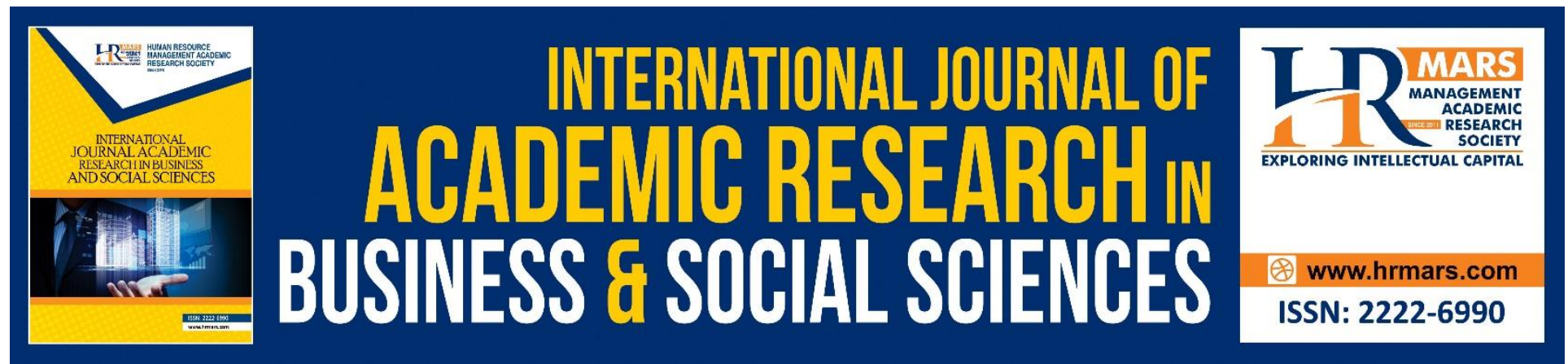

\title{
Assessing Housing Design Sustainability Using Urban Fabric Indicators: A Case Study of Middle Range High Rise Housing Development at Bandar Perda
}

\author{
Aizazi Lutfi Ahmad, Halmi Zainol, Kushairi Rashid, Mohd Sabri Mohd Arip \\ and Muhamad Azrul Azwan Azman
}

To Link this Article: http://dx.doi.org/10.6007/IJARBSS/v9-i11/6767

DOI: 10.6007/IJARBSS/v9-i11/6767

Received: 19 September 2019, Revised: 20 October 2019, Accepted: 02 November 2019

Published Online: 24 November 2019

In-Text Citation: (Ahmad et al., 2019)

To Cite this Article: Ahmad, A. L., Zainol, H., Rashid, K., Arip, M. S. M., \& Azman, M. A. A. (2019). Assessing Housing Design Sustainability Using Urban Fabric Indicators: A Case Study of Middle Range High Rise Housing Development at Bandar Perda. International Journal of Academic Research in Business and Social Sciences, 9(11), 1570-1584.

\section{Copyright: @ 2019 The Author(s)}

Published by Human Resource Management Academic Research Society (www.hrmars.com)

This article is published under the Creative Commons Attribution (CC BY 4.0) license. Anyone may reproduce, distribute, translate and create derivative works of this article (for both commercial and non-commercial purposes), subject to full attribution to the original publication and authors. The full terms of this license may be seen

at: http://creativecommons.org/licences/by/4.0/legalcode

Vol. 9, No. 11, 2019, Pg. 1570 - 1584

http://hrmars.com/index.php/pages/detail/IJARBSS

JOURNAL HOMEPAGE

Full Terms \& Conditions of access and use can be found at http://hrmars.com/index.php/pages/detail/publication-ethics 


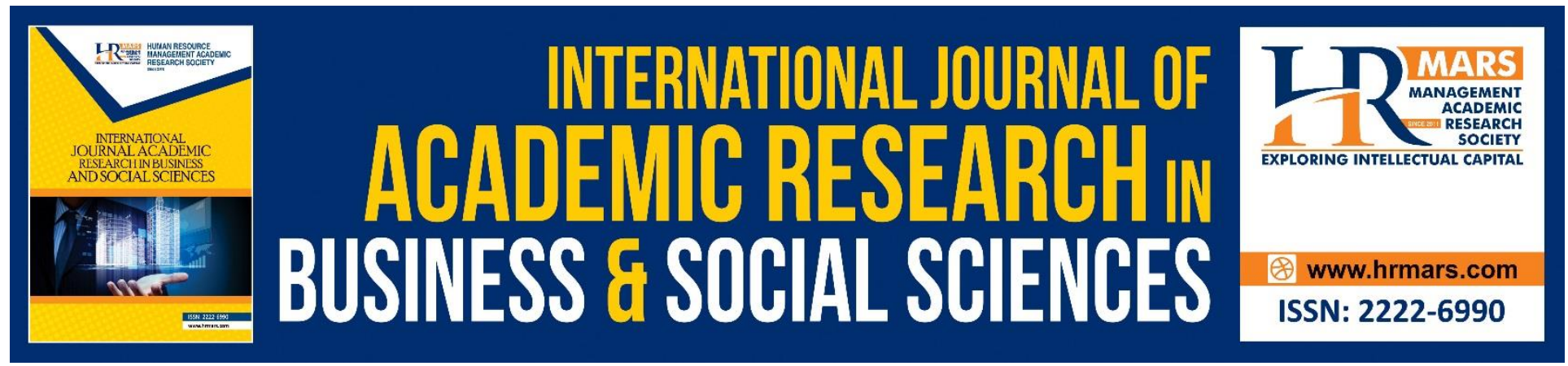

\title{
Assessing Housing Design Sustainability Using Urban Fabric Indicators: A Case Study of Middle Range High Rise Housing Development at Bandar Perda
}

\section{Aizazi Lutfi Ahmad, Halmi Zainol, Kushairi Rashid, Mohd Sabri Mohd Arip and Muhamad Azrul Azwan Azman}

Department of Town and Regional Planning, Faculty of Architecture, Planning and Surveying, Universiti Teknologi MARA, Perak Branch, Seri Iskandar Campus, 32610 Seri Iskandar, Perak, Malaysia.

\begin{abstract}
A residential area is a vital element in human life. Therefore a residential areas should be designed to create a balance between physical buildings, surrounding conditions, and residents. Nowadays, there is a lot of issues arises about sustainability of residential development in Malaysia mainly due to poor residential design that increases dependency on private vehicle, poor connectivity and encourages unhealthy live style. Although there are significant numbers of residential areas developed with sustainability concept is broadcasted as the key theme. However, the housing project is far from meeting the criteria for sustainable residential areas. This mainly due to the inability of a suitable measure to gauge the level of sustainability for residential design. Hence, this paper tried to investigate the sustainability of a mid-range high rise housing at Bandar Perda, Pulau Pinang using Sustainable Development Indicators (SDI) with urban fabric as the key components. The study applies a qualitative research method that applied observation and building inventory techniques used as key strategies to address the study objectives. The finding shows that Bandar Perda does fall short of achieving the sustainable values. Therefore proactive strategies by improving connectivity between areas should be considered. This study also found that indices of urban fabric are appropriate for measuring the sustainability of residential regions especially for medium range residential areas in Malaysia.
\end{abstract}

Keywords: Sustainable Development Indicator (SDI), Urban Fabrics, High Rise Residential, Medium Cost, Building. 


\section{Introduction}

Like other developing countries, Malaysia is still advancing in understanding the concept of sustainable development, particularly in housing. Sustainability efforts, especially in the housing industry is progressing thus becomes an vital innovation incorporated into every aspect of housing development stages. Housing also is an essential component of the economy where it has been the government's policy to place a roof over the head of every citizen. In this line, development of housing scheme based on sustainable development principles are gained attention especially from housing developers (Darus, Norisma, Ismail \& Novalia, 2011), Despite the fact that housing developers have made sustainability a main theme for their housing development, they do not seem to satisfy the requirements for sustainable homes, so the idea is used simply for marketing strategies. Therefore, the needs to measure the sustainability of housing is paramount and require attentions.

It is interesting to the point that Porta and Renne (2005) used 'Sustainable Development Indicator' (SDI) developed by the Ministerial Planning of Western Australia in their attempt to study extend of sustainability in housing design. In determining sustainability, the SDI measures eight indicators of urban fabric; accessibility, variety of land use, public / private space, natural surveillance, permeability, density of jobs and amount of buildings / lots. The application is helpful because it enables the capacity to detail the sustainability of street and neighborhood housing design that can help local enforcement organizations identify ' excellent ' and ' bad ' housing systems.

The SDI has become an important tool applied in this study as an assessment technique to determine the level of sustainability at mid-range high rise housing category development in Bandar Perda, Pulau Pinang (a middle range of housing scheme). Relation to that, this paper is driven by two important objectives; 1 ) to describe the tool for assessing and show off the applying assessment for mid-range high rise housing category concept by using SDI via urban fabrics; 2 ) to measure the level of sustainability for medium high-rise housing scheme.

This paper comprises of four sections. The first section is a literature review that explains SDI via urban fabric indicators. This section also highlights the concept of sustainability, characteristics and the sustainability requirement in mid-range high rise housing category. The second section discusses the methodology used for this study. The third section highlighted analysis and key findings of the study based on the SDI via the urban fabric. The forth section concludes this study by outlines the main contribution of the study to the body of knowledge and industry players.

\section{Theoretical Background Concept of Sustainability}

Based on McDonough (1992), the concept of sustainability introduced to a mixture of well-being concern with constant growth and human development. Although there is a lot of discussion about what the term implies, the research discovers the definition provided by the World Environment and Development Commission (1987): "Meeting current requirements without 
compromising future generations capacity to satisfy their own requirements" suit the purpose of the study. This definition was obtained exclusively from the human point of perspective in its main context. To embrace the idea of a global ecology with intrinsic value, the meaning needs to be expanded so that all parts of nature can now and in the future meet their own needs.

Sustainability is a worldwide idea for responding to worldwide issues. Sustainability is described as balancing and protecting the culture, economy and environment of the future to satisfy today's requirements without compromising future generations ' capacity to satisfy their own requirements. A building's service life should be intended to exceed design life by meeting the demands of eco-performance without disturbing what the world has for the future generation. Sustainable design development seeks at taking environmental consideration, high standard quality of living and economic impacts in any construction project (Tapir, Yatim and Usman, 2005). Thus, in this definition, the meaning of sustainability, design and design for a sustainability need to understand comprehensively due to the interconnection between those elements.

\section{Concept of Design for Sustainability}

Buchanan (2001), offered a formal design description: "Design is the human power to creation, structure and realize goods that serve human beings for any individual's personal purpose." The definition provides a platform for developers to consider how their job can be adapted to satisfy sustainable requirements. This involves designers who, inspired by human creativity, alter the workplace. Design means that human needs and wishes are conceived and realized. Sustainability design needs knowledge of the complete brief and long-term effects of any environmental transition. Sustainable design aims at reducing adverse environmental effects and construction occupants ' health and convenience, thereby improving building performance. Sustainability's fundamental goals are to decrease non-renewable resource usage, minimize waste, and generate healthy, productive environments. Sustainable design is the design and realization of environmentally delicate and accountable speech as part of nature's changing matrix (Porta and Renne, 2005). In essence, each of these approaches has its values that are interrelated. Combining this aspect, it can give a comprehensive evaluation of various forms and structures within a built environment. Successful design not achieved with developing buildings in isolation, but must take into consideration how to fit between housing and spaces together in the town centre to create a better urban environment.

\section{Urban Fabric Indicators for Sustainable Development}

Urban fabric indicators are commonly used to measure the level of sustainability at the district or neighbourhood scale (Porta and Renne, 2005). It assumes that city centers or suburbs built traditionally are most sustainable in terms of social equity, financial stability, and environmental protection or improvement compared to locations intended conventionally. Table 1 shows the listing of eight (8) urban fabric indicators to measure sustainable development. 
Table 1. Eight (8) Urban Fabric Indicators

\begin{tabular}{|c|c|c|}
\hline No. & Indicators & Description \\
\hline 1. & $\begin{array}{l}\text { Accessibility } \\
\text { (Pedsheds) }\end{array}$ & $\begin{array}{l}\text { - Pedshed or walkable catchment allows for an evaluation of the } \\
\text { interconnectivity and availability of the pedestrian road network. } \\
\text { - The pedshed demonstrates the percentages of a genuinely } \\
\text { available circle based on security, sidewalk and road design. }\end{array}$ \\
\hline 2. & Land Use Diversity & $\begin{array}{l}\text { - Measurement of land use diversity within the walkable catchment } \\
\text { region. } \\
\text { - A strong diversity price may boost customer choice by raising the } \\
\text { level of urban lifestyle servicing without raising the need for } \\
\text { motorized movement. }\end{array}$ \\
\hline 3. & Private / Public realm & $\begin{array}{l}\text { - The public sphere identifies where the public can or can not go } \\
\text { (where the public is unable to access } 24 \text { hours a day easily). } \\
\text { - The public domain region may include public parks and open } \\
\text { spaces, roads and sidewalks, and public parking lots at any } \\
\text { moment. }\end{array}$ \\
\hline 4. & $\begin{array}{l}\text { Natural monitoring } \\
\text { (Fronts and Backs) }\end{array}$ & $\begin{array}{l}\text { - Increased safety for pedestrians because of the sensation of ' eyes } \\
\text { on the roads ' (Jacobs, 1961) and increased territorialization } \\
\text { capacity for residents and users (Newman, 1973, 1996). } \\
\text { - Front and back mapping will recognize road regions with active } \\
\text { front construction helping to improve natural road monitoring. }\end{array}$ \\
\hline 5. & $\begin{array}{l}\text { Permeability } \\
\text { (Connectivity to streets) }\end{array}$ & $\begin{array}{l}\text { - Type and number of junctions in an region affect user motion in } \\
\text { that space and road network user readability. } \\
\text { - Type and number of junctions in an region affect user motion in } \\
\text { that space and road network user readability. } \\
\text { - T-junctions provide a decreased movement option and force a } \\
\text { change of direction. } \\
\text { - Cul-de-sacs are extremely unwanted as they interrupt the motion } \\
\text { flow. }\end{array}$ \\
\hline 6. & Workforce Density & $\begin{array}{l}\text { - Employment density relates to the average floor room per } \\
\text { individual in an occupied building (in sqm or sqft). } \\
\text { - Consequently, it is a measure of how much room each individual } \\
\text { has in the workplace. }\end{array}$ \\
\hline 7. & Number of Buildings & \multirow{2}{*}{$\begin{array}{l}\text { - The final elements in these indices assist to indicate the } \\
\text { measurement area scale. } \\
\text { - The statistics indicate that the distinct road layouts produce quite } \\
\text { distinct performances in terms of both the amount of } \\
\text { independent houses and the amount of houses. }\end{array}$} \\
\hline 8. & Numbers of Lots & \\
\hline
\end{tabular}

Source: Porta and Renne (2005) 


\section{Concept of Housing}

Housing is a fundamental need and a human right. It is impossible to underestimate the role that housing plays in a country's social and economic development. Government intervention in housing is commonly recognized as one of the ways in which the social aspect of citizens lives can be affected, in particular by mass housing otherwise known as social housing (Olugbenga, Yusoff, Aziz and Baba, 2017). The idea is comparable to that of the World Health Organization (1961), which defines housing as the residential setting, neighborhood, micro-district, or physical structure that humanity utilizes for shelter, and the atmosphere of that structure includes all the services / facilities, facilities, and devices necessary for the family and people physical health and social well-being. Based on the various ideas and concepts of studies, housing means, not only the physical structure but housing fulfil the survival needs but also other types of needs such as security, social esteem and even actualisation of needs (Randeniya, Ranasinghe and Amarawickrama, 2017). Housing can therefore be described as one of the most significant human requirements. It contributes to the decisive factor in developing not only for the residents' itself but can be as determining factor for economic, social and environmental development for specific places.

\section{Sustainable Development: A New Perspective for Housing Design}

A review from Lukuman, Ibrahim, Fauziah \& Aderemi (2017) stated that the sustainability of a housing implies the important factors of social well-being, economic development and health of the residents. Sustainable, livable housing is a prerequisite for healthy living, improving quality of life and making financial and social survival critical. It also covers multiple elements that are predominantly dependent on local circumstances of financial, social, cultural and environmental (ESCE).

Meanwhile, based on Said, Osman, Shafiei, Razak \& Kooi (2015), Concerns about urban growth and development on emissions, congestion, fuel use and types of construction have been discussed in various ways around the globe. Similarly, to tackle environmental and sustainability issues, scheduling schemes and regulatory frameworks are amended. Natural housing is multifaceted; it consumes natural resources and has an effect on the natural environment. Housing placement, construction materials, occupancy requirements, consumption of energy and water and other element of growth have significant environmental implications.

One of the prevalent variables affecting the overall economy may be housing. Housing is also an significant element of social growth, cultivating cultural attributes, a manifestation of aesthetic value and lifestyle. To map the future of housing development with the paradigm of sustainable development, a holistic perspective is required (Chiu, 2003). Housing-Corporation (2002) identified as follows the primary objectives of sustainable housing development (accessible housing):

i. Durable and reliable;

ii. Cost effective to build and to maintain; 
iii. Use natural resources and materials efficiently based on their life-cycle environmental impacts;

iv. Conserve water, reduces runoff and treats waste-on site;

v. Maximizing energy conservation and effectiveness; maximizing energy efficiency and energy conservation;

vi. Reduce footprints of construction, simplify forms of construction and maximize space effectiveness;

vii. Optimize the orientation of the construction to incorporate daylight and ventilation;

viii. Healthy by removing damaging and toxic materials in installations and surroundings;

ix. Support options to transport;

x. $\quad$ Reduce, reuse and recycle materials in all building and deconstruction stages;

xi. Apply maintenance and operating methods that decrease or eliminate damaging human and environmental impacts; and

xii. Flexibility, extension design for the future and capable of secure and effective demolition of buildings.

As such, a way forward for sustainable housing comprehension is by considering the needs of resident need along with the natural environment preservation.

\section{Methodology}

This study employed a qualitative approach to address the aim and research objectives. This involved observation and building inventory technique to complete the data collection process. The observation technique studies space representation in the area of research. The representation of space in the study region is based on complete space or land use: Diversity and permeability of land use (road connectivity). Meanwhile, the buildings inventory technique records the number of buildings and types of building use which is located in the study area. Therefore, the data are summarised by using two types of analysis; content analysis (for the observation) and spatial analysis (building inventory). The analysis on observation (content analysis) was focused on showing percentages of land use pattern and surrounding buildings. The data is gathered and compiled in the table to identify the main land use pattern of the area. This involves showing the best lot, land use or space that can and has shown a strong impact on sustainable development. Furthermore, spatial analysis (building inventory) is done by mapping each indicator of the urban fabric. The indicators of the urban fabric that contributed to the study were identified. These allow for an in-depth comparison between indicators. Only three indicators; land use diversity, permeability and number of buildings used to assess sustainability in the study area due to time limitation and only involved assessment within the walkable catchment or 1000 meters radius.

\section{Study Area}

Bandar Perda is planned residential township located at Seberang Perai, Pulau Pinang. Bandar Perda is an integrated township that is consist of commercial, residential, services and recreational activities. Currently, the township main commercial areas which are AEON Seberang 
Prai City Mall and ASEANIA Mall is the centre of attraction that offers residents with fine dining options and variety of stores to shop. Other amenities include are KPJ Hospital and the Bandar Perda Mosque nearby. Bandar Perda is a privatized project conducted jointly with the Penang Regional Development Authority (PERDA) by ASEANIA Development Sdn. Bhd. Since its privatization in November 1994, more than one-third of the total 456-acre township has been effectively created in Phase 1 and Phase 2 with multiple residential, industrial and commercial properties.

The study area is approximately 162.644 acres ( 65.820 hectares) that composed by commercial areas, office, residential, education institutional, government institutions, supermarket, mosque, open space and others. Within site, there are si6x blocks of an apartment that covers 23.586 acres (9.545 hectares) of the total township. With each block consist of 228 units, the total residential unit in this area is 1368 units. Each household was provided with 1 unit of parking space.

This site was selected because the study area fits the characteristic of a new township that composed of mixed development elements. This is pivotal to portray significant relationship between residential areas with services, amenities and commercial. Also, the location of the study area which lies between the two towns, Bukit Mertajam and Seberang Jaya able to show the importance of continuity of development based on sustainable development concept. As such, Bandar Perda is located in a strategic area that can deliver functionality to the city itself and its' adjacent area, especially for residents. The selection also based on the availability of low medium cost apartment and concern of sustainability living for medium income household.

\section{Result and Discussion Land Use Diversity}

Table 2 shows a result for land use diversity within 500 meters to 1000 meters locates from Mutiara Condominium. The analyses divided into three distances namely 500 meters, 800 meters and 1000 meters because it only measures land use variety within the walkable catchment area. The distances are also chosen because they indicate the continuity of land use and the facilities offered to the locals especially for the middle range housing residents. 
INTERNATIONAL JOURNAL OF ACADEMIC RESEARCH IN BUSINESS AND SOCIAL SCIENCES

Vol. 9, No. 11, November, 2019, E-ISSN: 2222-6990 ㄷ 2019 HRMARS

Table 2. Findings for Land Use Diversity Indicators

\begin{tabular}{|c|c|c|}
\hline Catchment Area & Land Uses Identified & Contribution Factors \\
\hline \multirow{6}{*}{500 Meters } & Low-Cost Apartment & Residential \\
\hline & Primary and Secondary School & Education Institution \\
\hline & Vacant Land & Vacant Land \\
\hline & Recreation Area & Landscape and Recreation \\
\hline & Mosque & Religion Institution \\
\hline & Seberang Perai City Council & Government Institution \\
\hline \multirow[t]{13}{*}{800 Meters } & KPJ Hospital & Health Services \\
\hline & Vacant Land & Vacant Land \\
\hline & R \& D for UiTM & Education Institution \\
\hline & Commercial Lots & Economic/ Commercial \\
\hline & Low-Cost Apartment & Residential \\
\hline & Open Space & Landscape and Recreation \\
\hline & Commercial Lots & Economic/ Commercial \\
\hline & Offices & Economic/ Commercial \\
\hline & Commercial Lots & Economic/ Commercial \\
\hline & Offices & Economic/ Commercial \\
\hline & Vacant Land & Vacant land \\
\hline & Banking & Services \\
\hline & Lembaga Hasil Dalam Negeri & Government Institution \\
\hline \multirow[t]{11}{*}{1000 Meters } & Vacant Land & Vacant Land \\
\hline & Commercial Lots & Economic/ Commercial \\
\hline & Low-Cost Apartment & Residential \\
\hline & Commercial Lots & Economic/ Commercial \\
\hline & Offices & Economic/ Commercial \\
\hline & Banking & Services \\
\hline & TNB & Government Institution \\
\hline & Pusat Urus Zakat & Government Institution \\
\hline & Entertainment Area & Economic/ Commercial \\
\hline & Commercial Lots & Economic/ Commercial \\
\hline & Offices & Economic/ Commercial \\
\hline
\end{tabular}




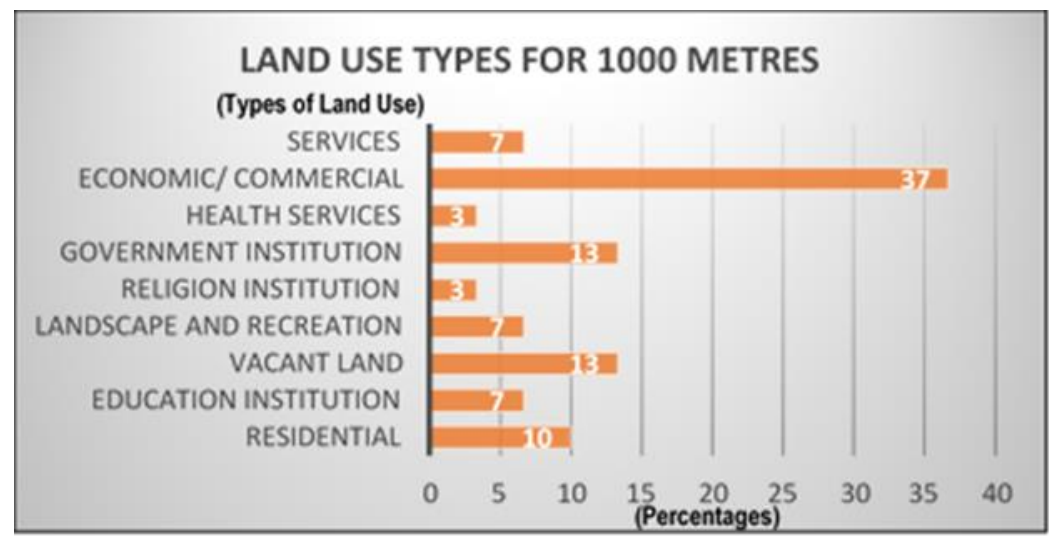

Figure 1. Percentages of Land Use Types For 1000 Meters in Bandar Perda

From Table 2 and Figure 1, the study identified the main contributing factors for land uses mixed in the study area are economic or commercials (37\%), government institutions (13\%), vacant land $(13 \%)$ and residentials (10\%). This shows that residential land use is secondary activity in Bandar Perda that support main activities which are government institution and commercial. The study also identified that Bandar Perda were lack of services, landscape and recreation, education institution and religion institution activity, therefore fall shorts in forming a sustainable living environment. In an address this, future development is recommended to instil better mixed of land use activities primarily components of services, landscape and recreation, education institution and religion institution.

\section{Permeability}

The measurement of permeability is based on the quantity and types of the road intersection within the radius of 1000 meters from Mutiara Condominium. As such, the study believes that the high number of junctions correlated with a high level of permeability that resulted in better connectivity. There are three kinds of junctions recognized in the research region, namely Fourway intersections, T-junctions and Cul-De-Sacs. The result for permeability analyses is shown in Table 3 as below: 
INTERNATIONAL JOURNAL OF ACADEMIC RESEARCH IN BUSINESS AND SOCIAL SCIENCES Vol. 9, No. 11, November, 2019, E-ISSN: 2222-6990 @ 2019 HRMARS

Table 3. Result for Permeability Indicator in Bandar Perda, Pulau Pinang

\begin{tabular}{|c|c|c|}
\hline Types Of Intersection & Quantity & Percentages \\
\hline \multicolumn{3}{|l|}{ 1) Four-Way Intersection } \\
\hline Northern and West Area & 3 & $2.4 \%$ \\
\hline Eastern Area & 12 & $9.5 \%$ \\
\hline Southern Area & 4 & $3.2 \%$ \\
\hline Total A & 19 & $15.1 \%$ \\
\hline \multicolumn{3}{|l|}{ 2) T-Junctions } \\
\hline Northern and West Area & 7 & $5.5 \%$ \\
\hline Eastern Area & 44 & $35.0 \%$ \\
\hline Southern Area & 53 & $42.0 \%$ \\
\hline Total B & 104 & $82.5 \%$ \\
\hline \multicolumn{3}{|l|}{ 3) Cul-De-Sacs } \\
\hline Northern and West Area & 2 & $1.6 \%$ \\
\hline Eastern Area & 1 & $0.8 \%$ \\
\hline Southern Area & 0 & $0 \%$ \\
\hline Total C & 3 & $2.4 \%$ \\
\hline Grand Total $(A+B+C)$ & 126 & $100 \%$ \\
\hline
\end{tabular}

The study identified there were 126 junctions in total with T-junctions was recorded with 104 or $82.5 \%$ of total junctions, four-way intersections with 19 or $15.1 \%$ and cul-de-sacs with three units or $2.4 \%$. The T-junctions happen to be the most significant quantity mainly due to grid iron pattern design of the commercial areas, back lanes and fire breaks. Contrary, the four-way intersections were only identified at main roads while the cul-de-sacs junctions were hardly noticed especially in the housing areas.
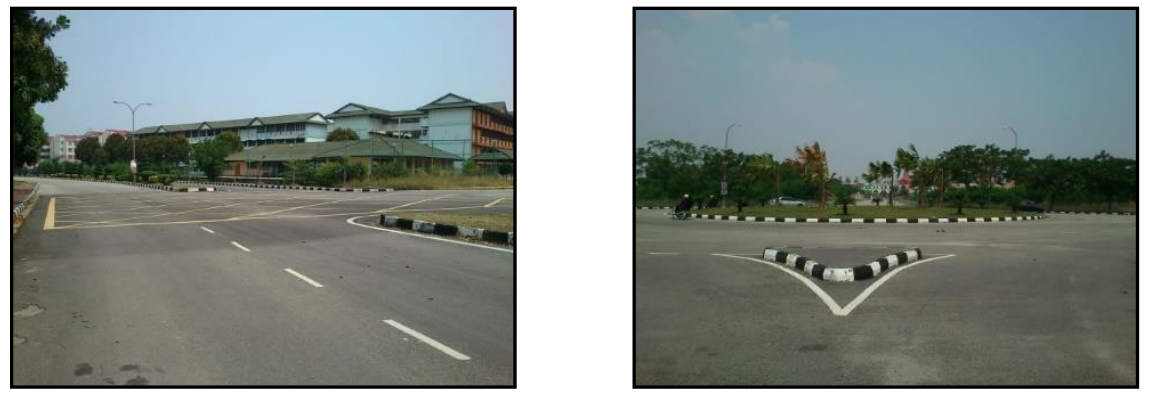

Photo 1. T-Junctions at North Area (left) and West Area (right)
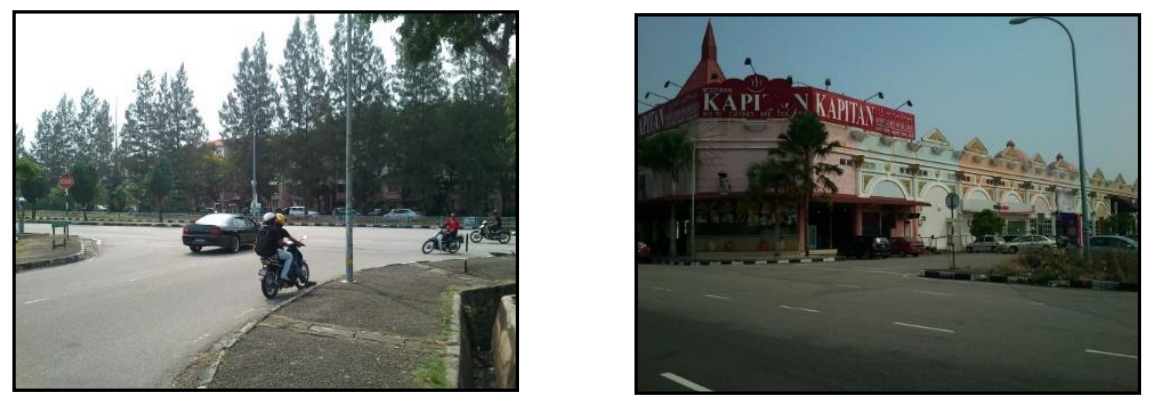
Photo 2. T-Junctions at East Area (left) and South Area (right)
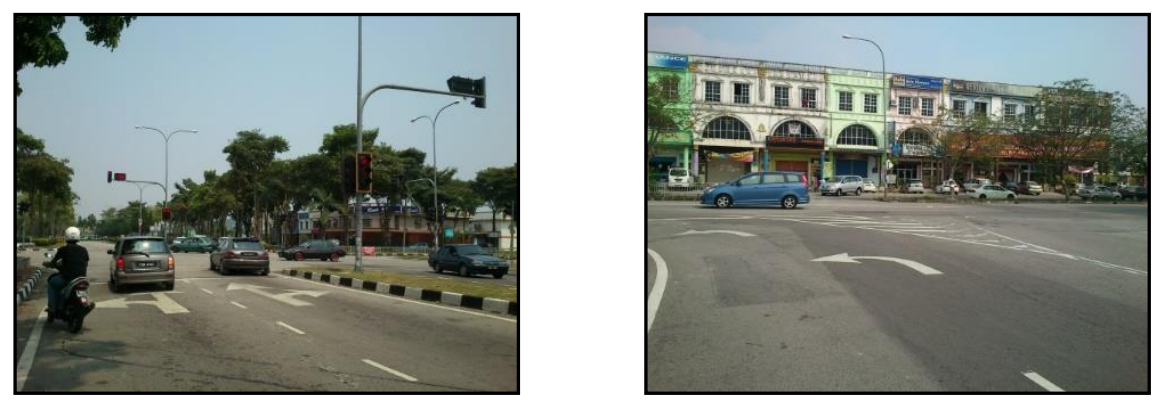

\section{Photo 3. Four-Way Intersections at North Area (left) and South Area (right)}
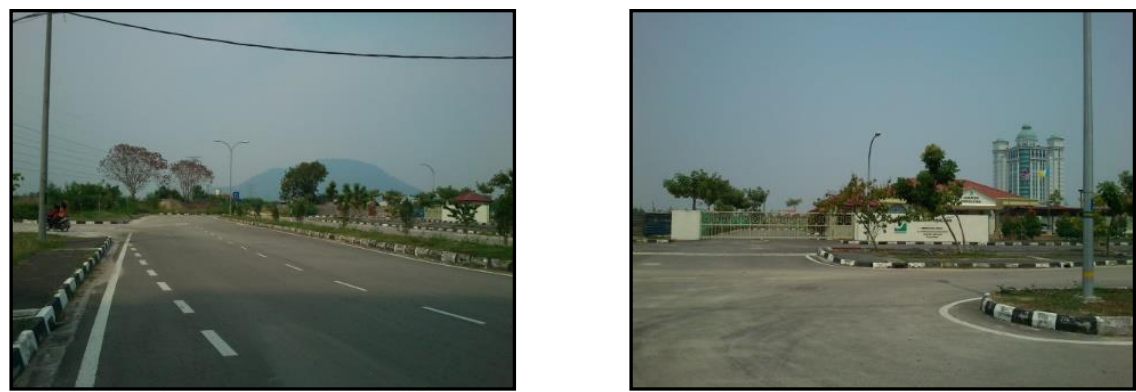

Photo 4. Cul-De-Sacs at North Area

Therefore, based on the permeability component, the study found that the area had good connectivity due to the high presence of T-junctions. However, the use of four-way junctions and cul-de-sacs, particularly for business and residential areas, while providing residents with greater safety (Azman et al., 2018), the design should be avoided to reduce possibility traffic conflict at the junction.

\section{Number of Buildings}

The study categorised building in the study area into two types which are landed property (terrace buildings) and free standing buildings. The number of buildings was measured based on the quantity of the buildings located at north, west, east and south area within 1000 meters' radius from Mutiara Condominium. As many terrace buildings often imply functional connectivity, availability of this house is assumed to provide better accessibility for the pedestrian. On the contrary, the numbers of free-standing building restrict entries, connectivity and sharing of activities. The result of the study is shown in Table 4. 
Table 4. Result for Number of Buildings Indicator

\begin{tabular}{|l|c|c|l|}
\hline \multicolumn{1}{|c|}{ Area } & Quantity & Percentages & \multicolumn{1}{c|}{ Category } \\
\hline 1) Landed Property (Terrace Buildings) \\
\hline Northern Area & 0 & $0 \%$ & None \\
\hline Western Area & 0 & $0 \%$ & None \\
\hline Eastern Area & 230 & $51 \%$ & Commercial Lots and Offices \\
\hline Southern Area Total & 220 & $49 \%$ & Commercial Lots and Offices \\
\hline \multicolumn{2}{|c|}{$\mathbf{4 5 0}$} & $\mathbf{1 0 0 \%}$ & \\
\hline 2) Free Standing Buildings & 18 & $46 \%$ & $\begin{array}{l}\text { Residential, Government } \\
\text { Institution, Religion Institution }\end{array}$ \\
\hline Northern Area & 2 & $5 \%$ & Government Institution \\
\hline Western Area & 16 & $41 \%$ & $\begin{array}{l}\text { Residential and Commercial } \\
\text { (Pump Station) }\end{array}$ \\
\hline Eastern Area & 3 & $\mathbf{8} \%$ & Government Institution \\
\hline Southern Area Total & $\mathbf{3 9}$ & $\mathbf{1 0 0 \%}$ & \\
\hline
\end{tabular}

The study identified that most of the terrace buildings were mostly located In the research region: north and south. Meanwhile for free-standing buildings that consist of high rise residential buildings and government institutional buildings were mostly identified at the east and north From the region of research. The analyzes based on the amount of buildings shown that there are still lacking terrace buildings in the study area that may result in good connectivity and accessibility for the pedestrian network. Therefore, to improve connectivity and subsequently sustainability of the area, the study recommended more terrace based design for building to be developed and better connectivity between free-standing buildings via pedestrian networks is needed for future development.

\section{Conclusion}

Malaysia has yet to introduce indicators that are cable to evaluate the level of housing sustainability within the mid-range high rise category. Hence, this paper investigates the sustainability of housing design by applying urban fabric indicators comprises elements that are available street and neighbourhood levels. As such, this study argues that measuring sustainability should consider land use diversity, street connectivity and network as important indicators for sustainable housing design. Planning for the sustainable design especially for housing development requires complete understanding of the brief and long-term effects of any transition that may have an effect on the living setting.

Especially on resident travel capability. Therefore, the study identified a successful design is not achieved with developing buildings in isolation, but must also take into consideration integration between spaces may or should be coexisted between housing areas. 
The finding proves that urban fabric indicators are an important measure to shows the level of sustainability of any residential design, thus can reveal poor spatial arrangement. From the results of the analysis, the study identified similar findings with (Rashid, 2013) that better mixed of land use activities primarily components of services, landscape and recreation, education institution and religion institution are pivotal in providing better accessibility to the resident. The study also identified good connectivity in the study area could be achieved by reducing four-way intersections and cul-de-sacs especially in commercial and housing areas. Thus, to improve the connectivity and accessibility for the pedestrian network, more terrace based housing design should be considered, while better connectivity between free-standing buildings via pedestrian networks provision able to improve accessibility for residents.

Considering the continuous challenges in providing sustainable housing design, application of the indictors to other types of house i.e. town house, detached or semi-detached house design, should able to give insight on the robustness of the measures to assess sustainable housing design. While, in achieving a good level of sustainability, the study highly recommends bettermixed house types, improved street connectivity and availability of social spaces between housing categories, as critical design strategies. The finding of the study has contributes to a better knowledge of the significance of diversity of land use, street connectivity and network toward sustainable residential design. Application of the measures certainly not only help planners and designers to determine shortfalls of housing design but importantly able to determine appropriate strategies which are important to attain good degree of sustainability in their residential development design.

\section{Acknowledgement}

Thank you very much to my employer Universiti Teknologi MARA (UiTM) Perak Branch for supporting and permitting this study job. Thousand thanks also credited as the Research Area Authority to Seberang Perai Municipal Council, Pulau Pinang (MPSP) and Penang Development Authority (PERDA). Special thanks to the panels and anonymous reviewers and publishers. Finally, for the assistance and workmanship provided to team members for this studies.

\section{Corresponding Author}

Aizazi Lutfi Ahmad, Department of Town and Regional Planning, Faculty of Architecture, Planning and Surveying, Universiti Teknologi MARA, Perak Branch, Seri Iskandar Campus, 32610 Seri Iskandar, Perak, Malaysia. Email: aizaz232@uitm.edu.my

\section{References}

Azman, M. A. A., Zainol, H., Ali, N. E. H., \& Rashid, K. (2018). Determining Factors of Community Safety to Combating Crime in Neighborhood Residential. International Journal of Academic Research in Business and Social Sciences, 8(5), 608-620.

Buchanan, R. (2001). Design Research and the New Learning. MIT Press Journals. Design Issues Volume 17, Issue 4, Autumn 2001, p.3-23. 
Chiu, R. L. H. (2003). Sustainable Development; A New Perspective For Housing Development. The University of Hong Kong.

Darus, Z. M. D., Norisma, W., Ismail, W. R., \& Novalia, R. (2011). A Conceptual Approach in Sustainable Housing in Malaysia. International Journal of Environmental, Cultural, Economic and Social Sustainability, 7(3), 225-235.

Housing-Corporation. (2002). The Housing Corporation: Sustainable Development. Retrieved May, 2008, from www.housingcorp.gov.uk/resources/sustain.html.

Krippendorff, K. (2004). Content Analysis : An Introduction to Its Methodology (Second Edition). California : Sage Publication Inc.

Lukuman, M., Ibrahim, S., Fauziah, R., \& Aderemi, O. S. (2017). Sustainable Livable Housing: A Review of What Traditional Urban Areas Residents Find Important. International Journal of Built Environment and Sustainability, IJBES 4(3)/2017, 190-198.

McDonough, W. (1992). The Hannover Principles : Design for Sustainability. Hannover, Germany : Prepared for EXPO 2000 The World's Fair Hannover, Germany.

Olugbenga, T. D., Yusoff, N., Aziz, N. A., \& Baba, A. N. (2017). Unleashing the Potentials of Housing Sector in Nigeria as Perceived by Users. International Journal of Built Environment and Sustainability, IJBES 4(3)/2017, 172-179.

Porta, S., \& Renne, J. L. (2005). Linking Urban Design to Sustainability: Formal Indicators of Social Urban Sustainability Field Research. Perth, Western Australia: Urban Design International.

Rashid, K. (2013). A methodology to develop an urban transport disadvantage framework: the case of Brisbane, Australia (Doctoral dissertation, Queensland University of Technology).

Rozana, Z. (2007). Sustainable Housing for Residential-Industrial Neighbourhoods in Malaysia - A Study on the Elements of Indoor Environmental Quality Improvements. Australia.

Said, I., Osman, O., Shafiei, M. W. M., Razak, A. A., \& Kooi, T. K. (2015). Sustainability in the Housing Development Among Construction Industry Players in Malaysia. School of Housing Building Planning, Universiti Sains Malaysia.

Tapir, S. H., Yatim, J. M., \& Usman, F. (2005). Towards Better Housing Management: Service Life Planning In Achieving Sustainability for Affordable Housing. 10.4203/ccp.81.73.

Tapir, S. H. (2001)."Final Report: Affordable Housing Research Project -Life Cycle Costing Approach for Residential Housing in Malaysia Phase-1 ", Ministry of Housing and Local Government, Malaysia, 65-72.

Randeniya, T. D., Ranasinghe, G. \& Amarawickrama, S. (2017). A Model to Estimate the Implicit Values of Housing Attributes by Applying the Hedonic Pricing Method. International Journal of Built Environment and Sustainability, IJBES 4(2)/2017, 113-120.

United Nations General Assembly. (1987). Report of The World Commission on Environment and Development: Our Common Future. Oslo, Norway: United Nations General Assembly, Development and International Co-operation: Environment.

World Health Organization. (1961). Expert Committee on the Public Aspect of Housing. Technical Report Series, 225. 